\title{
SMART KULKAS DENGAN FITUR SMS UNTUK MELAPORKAN KETERSEDIAAN BAHAN MAKANAN
}

\author{
I Wayan Degeng ${ }^{1}$, Michael Santoso ${ }^{2}$ \\ Program Studi Sistem Komputer, Fakultas Teknologi Informasi, Universitas Budi Luhur, Jakarta \\ iwayandegeng@yahoo.com, michaelsantoso9006@gmail.com
}

\begin{abstract}
Abstrak
Kulkas atau lemari es atau refrigerator merupakan salah satu alat rumah tangga yang dipakai seharihari untuk menyimpan bahan makanan agar tetap segar. Untuk mengetahui apakah isi kulkas hampir habis atau sudah habis, maka pengguna harus mengecek langsung pada kulkas itu dengan membuka pintu kulkas dan melihat isinya secara visual. Jika pengguna sedang berada di luar rumah dan ingin mengetahui apakah isi kulkas masih ada, maka ia harus menelpon ke rumah sehingga merepotkan. Solusi yang ditawarkan adalah dengan melakukan modifikasi pada kulkas sehingga pengguna dapat mengecek isi kulkas melalui handphone dengan mengirim pesan singkat (SMS) dan kulkas dapat pula mengirim notifikasi melalui SMS ke pengguna jika isi kulkas mendekati habis. Peralatan yang ditambahkan pada kulkas adalah mikrokontroler dalam Arduino Uno R3 yang dilengkapi dengan load sensor, dan sensor infrared sebagai pendeteksi makanan dan dengan modul GSM untuk mengirim dan menerima pesan singkat. Penelitian ini merancang modifikasi kulkas dan melakukan pengujian pada hasil modifikasi itu. Hasilnya adalah sistem smart kulkas yang dapat mengirim pesan singkat SMS jika persediaan makanan di dalam kulkas kurang.
\end{abstract}

Kata Kunci: modifikasi, kulkas, SMS, GSM, load sensor

\begin{abstract}
Refrigerator is one of household appliances used daily to keep foodstuffs fresh. To find out whether the contents of the refrigerator are running low or run out, a user must check it directly by opening the door and viewing the contents. It will be troublesome to know the contents of the refrigerator when the user is outdoors because he or she must first call someone at home. One of solutions offered is by modifying the refrigerator so that the user can check the contents of the refrigerator by sending a short message (SMS) via mobile phone and the refrigerator can also send notification via SMS to the user if the contents of the refrigerator are running out. Equipment added to the refrigerator is a microcontroller in Arduino Uno R3 equipped with load sensors, and infrared sensors as food detectors and with GSM module for sending and receiving short messages. The study is conducted to design a modified refrigerator and to test the modification result. The result is a smart refrigerator system that can send SMS if the food supply in the refrigerator is running out.
\end{abstract}

Keywords: modification, refrigerator, SMS, GSM, load sensor

\section{Latar Belakang}

\section{PENDAHULUAN}

Kulkas dipakai sehari-hari untuk menyimpan bahan makanan agar tetap segar. Pengguna harus mengecek kulkas setiap hari untuk mengetahui apakah isinya masih cukup, hampir habis atau sudah habis. Jika pengguna sedang berada di luar rumah, maka pengguna harus menelpon ke rumah untuk mengecek isi kulkas dan menambahkan bahan makanan yang perlu dibeli ke dalam daftar belanja. Pekerjaan mengecek isi kulkas sangat merepotkan sehingga ditawarkan melakukan modifikasi kulkas menjadi suatu smart kulkas yang dapat mengirim pesan singkat (SMS) ke pengguna kulkas melalui handphone jika isi kulkas mendekati habis. Pengguna dapat berinisiatif mengirim pesan singkat kepada kulkas untuk mengetahui isi kulkas. Pengguna juga dapat mengirim SMS agar kulkas berhenti mengirim notifikasi mengenai persediaan bahan makanan di dalam kulkas. 
Baier, dan kawan-kawan telah mengusulkan sistem logistik terintegrasi antara pengguna, supplier, perusahaan logistik dan gudang makanan di rumah, yang memungkinkan supply kebutuhan sehari-hari secara otomatis dalam lingkungan smart home, dimana salah satu komponen sistem tersebut adalah smart kulkas. Isi smart kulkas diperoleh dengan mengambil foto setiap kali pintu kulkas dibuka, lalu mengimkannya kepada pengguna [1]. Masalah yang muncul adalah masalah pengiriman foto itu dan masalah bahan makanan yang tersembunyi di belakang bahan makanan lain tidak terdeteksi oleh kamera.

Beberapa riset juga telah melakukan cara lain untuk mengidentifikasi isi kulkas, yaitu dengan RFID, yang mengharuskan setiap bahan makanan diberi tag RFID agar dapat dikenali oleh sistem [2], [3], [4]. Dengan cara pemberian tag RFID ini menimbulkan masalah tersendiri menyangkut metode pemberian tag dan menyangkut harga tag RFID itu sendiri.

Penelitian lain [5] menyebutkan bahwa pengenalan makanan merupakan fungsi utama dari smart kulkas. Akan tetapi banyak tantangan untuk membuat pengenalan makanan menjadi akurat karena banyaknya jenis makanan yang ada di dalam kulkas yang cenderung saling menghalangi dan berbagai jenis makanan itu terlihat sangat mirip satu sama lain, karena itu dipakailah pengenalan makanan dengan memakai informasi berat makanan dan multi deep learning models. Cara ini dapat dengan signifikan meningkatkan akurasi pengenalan makanan. Meskipun demikiat akurat, cara ini memerlukan prosesing data yang tidak sederhana.

Sistem smart kulkas yang ditawarkan dalam penelitian ini adalah modifikasi yang memungkinkan kulkas dapat mengirim pesan singkat (SMS) ke pengguna kulkas melalui handphone jika isi kulkas mendekati habis. Pengguna dapat pula berinisiatif mengirim pesan singkat kepada kulkas untuk mengetahui isi kulkas. Pengenalan isi kulkas dilakukan dengan cara yang menempatkan sensor berat pada jenis makanan yang akan dideteksi, dan menempatkan sensor infrared pada jenis makanan yang sama atau jenis makanan lainnya.

\section{Tujuan Penelitian}

Tujuan pokok dari penelitian ini dapat dinyatakan untuk mencari jawaban atas pertanyaan, apakah suatu sistem smart kulkas dengan fitur SMS untuk melaporkan ketersediaan makanan dapat dibuat, dan apakah sensor deteksi berat makanan dapat bekerja dengan baik, dan apakah sensor infrared dapat bekerja dengan baik.

\section{METODE PENELITIAN}

Penelitian dilaksanakan dengan metode perancangan dan pengujian.

Langkah-langkah yang dilakukan adalah: pertama, menetapkan diagram blok sistem, kedua, menentukan komponen yang diperlukan, ketiga menentukan rangkaian keseluruhan sistem, keempat, menentukan diagram alur (flow chart) sistem dan terakhir adalah melakukan pengujian sistem.

\section{HASIL DAN PEMBAHASAN}

\section{A. Implementasi Sistem}

Implementasi dari sistem yang digunakan, terlebih dahulu direpresentasikan dengan diagram blok dengan masukan dan keluaran yang disesuaikan dengan kebutuhan. Penentuan setiap blok akan mempermudah langkah selanjutnya yaitu menentukan komponen yang diperlukan maupun langkah-langkah selanjutnya. Berikut ini adalah diagram blok sistem seperti ditunjukkan pada Gambar 1 . 


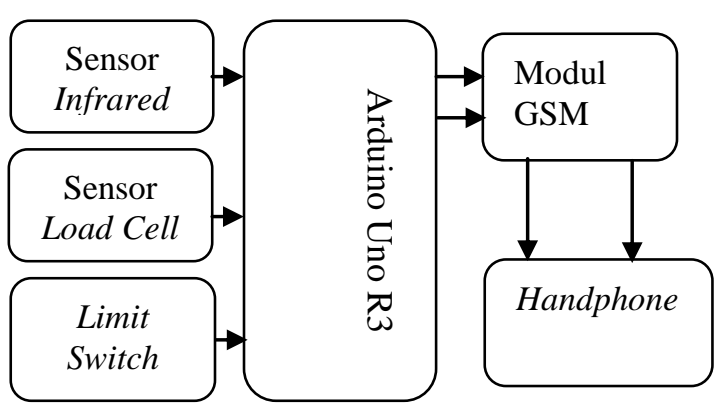

\section{Gambar 1. Diagram Blok Sistem}

Diagram blok di atas menjelaskan tentang Sistem Smart kulkas menggunakan mikroprosesor dalam Arduino Uno R3, lengkap dengan hubungan fungsional dengan masukan dan keluarannya.

Berikut keterangan diagram blok:

a. Sensor Infrared untuk mendeteksi ada tidaknya telor di dalam kulkas.

b. Limit Switch untuk mendeteksi apakah pintu kulkas terbuka atau tertutup.

c. Sensor Load Cell berfungsi untuk mendeteksi/mengukur berat beban yang ada diatasnya yaitu makanan di dalam kulkas.

d. GSM Shield berfungsi untuk mengirim dan menerima pesan singkat atau SMS (Short Message Service) pada nomor GSM pemilik kulkas.

e. Arduino Uno R3 bertindak sebagai mikrokontroler untuk mengatur dan menjalankan program, dimana Arduino ini akan memproses data dari sensorsensor masukan dan menghasilkan keluaran pada modul GSM.

\section{Komponen yang diperlukan:}

\section{Arduino Uno}

Arduino Uno R3 merupakan sebuah board mikrokontroler yang didasarkan pada ATmega328. Arduino Uno R3 memuat semua yang dibutuhkan untuk menunjang mikrokontroler, mudah dihubungkan ke sebuah komputer dengan sebuah kabel USB. Arduino Uno R3 memiliki 14 pin input/output digital (atau biasa ditulis $\mathrm{I} / \mathrm{O}$, dimana 6 pin diantaranya dapat digunakan sebagai output PWM), 6 pin input analog, menggunakan crystal $16 \mathrm{MHz}$, koneksi USB, jack listrik, header ICSP dan tombol reset. Hal tersebut adalah semua yang diperlukan untuk mendukung sebuah rangkaian mikrokontroler. Cukup dengan menghubungkannya ke komputer dengan kabel USB atau diberi power dari adaptor AC-DC atau baterai, Arduino Uno sudah dapat dijalankan. Berikut adalah gambar Arduino Uno R3 yang menunjukkan penomoran pin-pinnya [6].

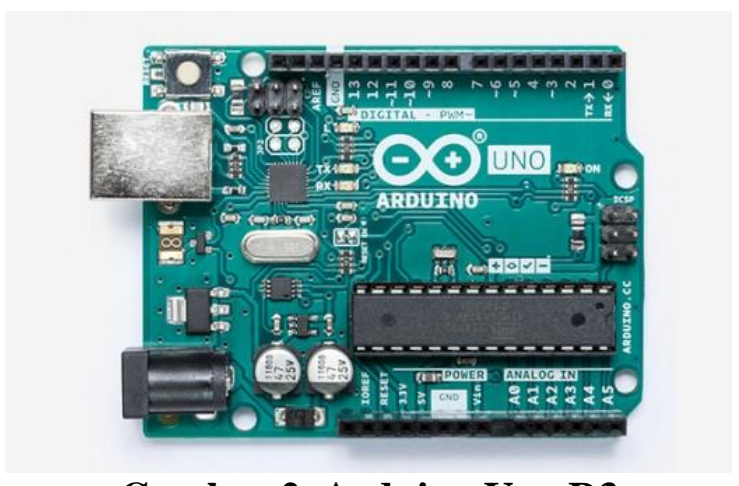

Gambar 2. Arduino Uno R3

Secara ringkas, berikut ini adalah spesifikasi Arduino Uno R3 yang diperoleh dari referensi yang sama:

Tabel 1. Spesifikasi Arduino Uno Rev3

\begin{tabular}{|l|l|}
\hline Microcontroller & ATmega328P \\
\hline Operating Voltage & $5 \mathrm{~V}$ \\
\hline $\begin{array}{l}\text { Input Voltage } \\
\text { (recommended) }\end{array}$ & $7-12 \mathrm{~V}$ \\
\hline Input Voltage (limit) & $6-20 \mathrm{~V}$ \\
\hline Digital I/O Pins & $\begin{array}{l}14 \text { (of which 6 provide } \\
\text { PWM output) }\end{array}$ \\
\hline PWM Digital I/O Pins & 6 \\
\hline Analog Input Pins & 6 \\
\hline DC Current per I/O Pin & $20 \mathrm{~mA}$ \\
\hline DC Current for 3.3V Pin & $50 \mathrm{~mA}$ \\
\hline Flash Memory & $\begin{array}{l}32 \mathrm{~KB} \text { (ATmega328P) } \\
\text { of which } 0.5 \mathrm{~KB} \text { used } \\
\text { by bootloader }\end{array}$ \\
\hline SRAM & $2 \mathrm{~KB}(\mathrm{ATmega328P})$ \\
\hline EEPROM & $1 \mathrm{~KB}(\mathrm{ATmega328P})$ \\
\hline Clock Speed & $16 \mathrm{MHz}$ \\
\hline LED_BUILTIN & 13 \\
\hline Length & $68.6 \mathrm{~mm}$ \\
\hline Width & $53.4 \mathrm{~mm}$ \\
\hline Weight & $25 \mathrm{~g}$ \\
\hline
\end{tabular}




\section{Sensor Infrared}

Sensor Infrared dikemas dalam sebuah modul infrared. Modul infrared sering dipakai sebagai sensor adanya penghalang (obstacle sensor), yang mudah dibuat, mudah dikalibrasi, dengan range deteksi $10-30 \mathrm{~cm}$. Sensor ini umumnya dapat dipakai untuk semua aplikasi indoor, dimana tidak banyak ada sinar matahari. Cara kerja pokoknya adalah dengan memancarkan sinar inframerah melalui LED infrared. Sinar ini akan dipantulkan kembali oleh benda-benda yang ada di sekitar sensor.

Fitur:

- Merupakan obstacle based IR detector

- Dapat disetel dengan POT

- Logic Output 1 atau 0

- Sensitivitas mencapai $30 \mathrm{~cm}$ dan dapat diatur.

Berikut adalah gambar modul infrared [7]:

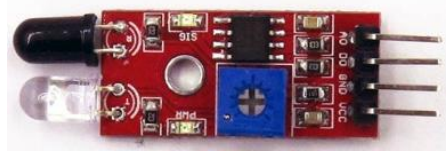

\section{Gambar 3. Modul Infrared}

\section{Sensor Load Cell}

Load Cell merupakan komponen utama pada sistem timbangan digital. Bahkan tingkat ke-akurasian suatu timbangan digital tergantung dari jenis dan tipe Load Cell yang dipakai. Load Cell adalah alat electromekanik yang biasa disebut Transducer, yaitu gaya yang bekerja berdasarkan prinsip deformasi sebuah material akibat adanya tegangan mekanis yang bekerja, kemudian merubah gaya mekanik menjadi sinyal listrik. Untuk menentukan tegangan mekanis didasarkan pada hasil penemuan Robert Hooke, bahwa hubungan antara tegangan mekanis dan deformasi yang diakibatkan disebut regangan. Regangan ini terjadi pada lapisan kulit dari material sehingga menungkinkan untuk diukur menggaunakan sensor regangan. Bentuk fisik dari beam type load cell tipe TAL 220 beserta fitur-fiturnya dapat dilihat pada gambar berikut ini [8]:

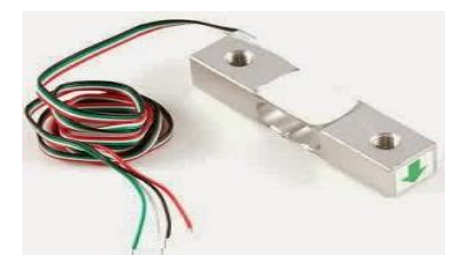

Gambar 4. Sensor Load Cell

Fitur:

- Kapasitas 3-50 kg

- Tipe: parallel beam type

- Material: alluminium alloy atau alloy steel

- Rated output $=1.0 \pm 0.15 \mathrm{mV}$

Dengan rated output yang rendah, maka diperlukan amplifier dan ADC untuk menguatkan dan memproses signal dari sensor. Komponen yang dipakai adalah ADC for weight scale tipe ADC HX711 dengan diagram sebagai berikut [9].

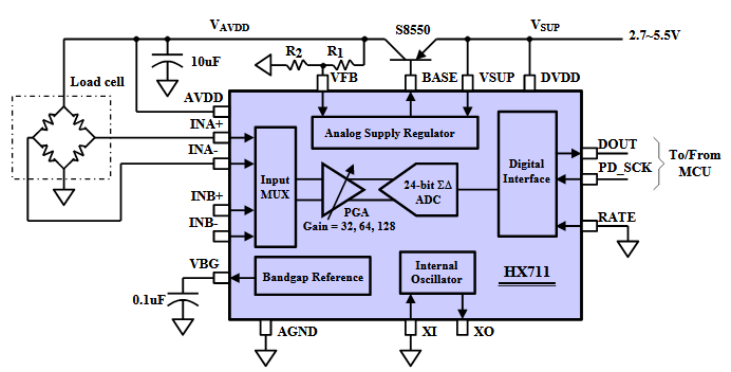

Gambar 5. ADC HX711

4. Modul GSM

SIM900 adalah modul Qual-band GSM/GPRS berbentuk SMT terbuat dari sebuah prosesor canggih ARM926EJ-S, sehingga ukurannya kecil $(24 \mathrm{~mm} \times 24 \mathrm{~mm} \times 3 \mathrm{~mm})$ dan merupakan solusi yang efektif sebagai modul komunikasi. SIM900A sudah menerapkan antarmuka standar industri 
dalam menyediakan fitur komunikasi GSM/GPRS 850/900/1800/ $1900 \mathrm{MHz}$ untuk voice, SMS, data, dan fax. Bentuk fisik modul GSM/GPRS SIM900A dapat dilihat pada gambar di bawah Modul GSM SIM900A dapat bekerja dengan diberi perintah "AT Command", (AT $=$ Attention). AT Command adalah perintah-perintah standar yang digunakan untuk melakukan komunikasi antara komputer dengan ponsel melalui serial port. Melalui AT Command, data-data yang ada di dalam ponsel dapat diketahui, mulai dari vendor ponsel, kekuatan sinyal, membaca pesan, mengirim pesan, dan lain-lain. Berikut ini adalah gambar yang menunjukkan modul GSM SIM900A [10]:

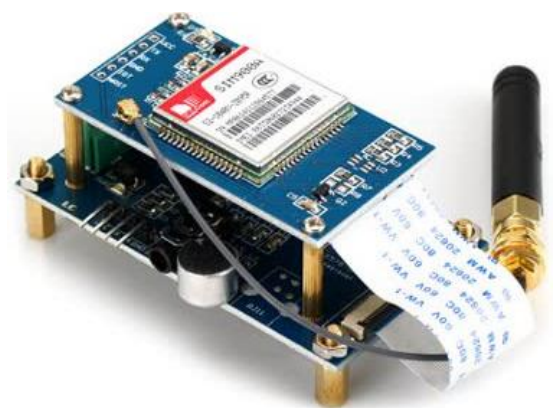

Gambar 6. Modul GSM SIM900A

\section{Cara Kerja Alat}

1. Setelah dihidupkan, maka mikrokontroler akan melakukan proses inisiasi dan kalibrasi.

2. Jika pintu kulkas tertutup, maka sistem akan membaca sensor infrared, dan membaca load sensor.

3. Jika sistem menerima SMS "SISA", maka sistem akan membalas dengan SMS jumlah telor dan berat bahan makanan.

4. Jika jumlah telor berkurang mencapai 3 dan atau berat bahan makanan kurang dari 150 gram, maka sistem akan mengirim SMS terus menerus setiap 5 detik sampai menerima balasan SMS dengan pesan "OFF".

\section{Rangkaian Keseluruhan}

Rangkaian keseluruhan ini terdiri dari Arduino Uno R3, Rangkaian Sensor Load Cell dengan ADC HX711, Rangkaian Modul GSM SIM900A, Rangkaian Sensor Infrared, dan Rangkaian Limit Switch.

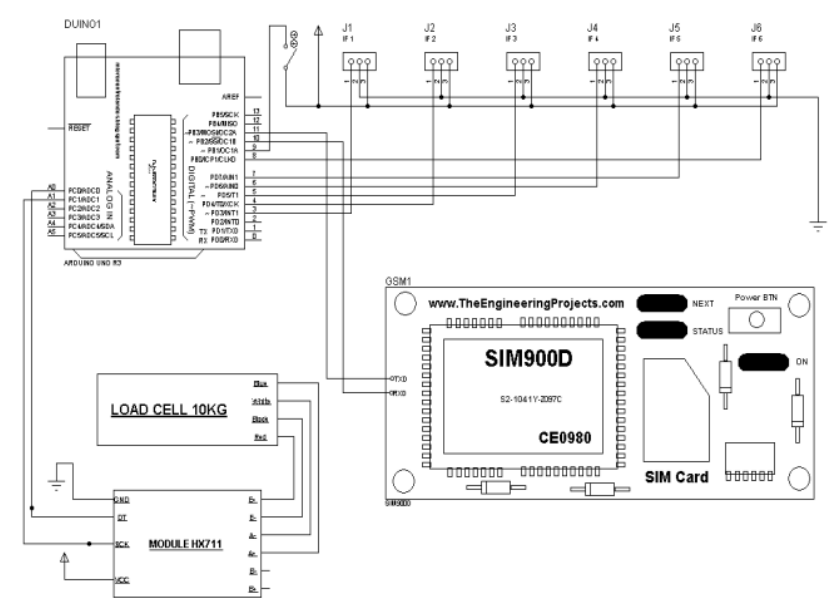

Gambar 7. Rangkaian Keseluruhan

\section{Flowchart}

Flowchart merupakan alur kerja alat dan cara berpikir dalam menulis program. Flowchart dibagi dua, yaitu flowchart alat merupakan flowchart global sedangkan flowchart keseluruhan menunjukkan alur proses yang lebih detail. 

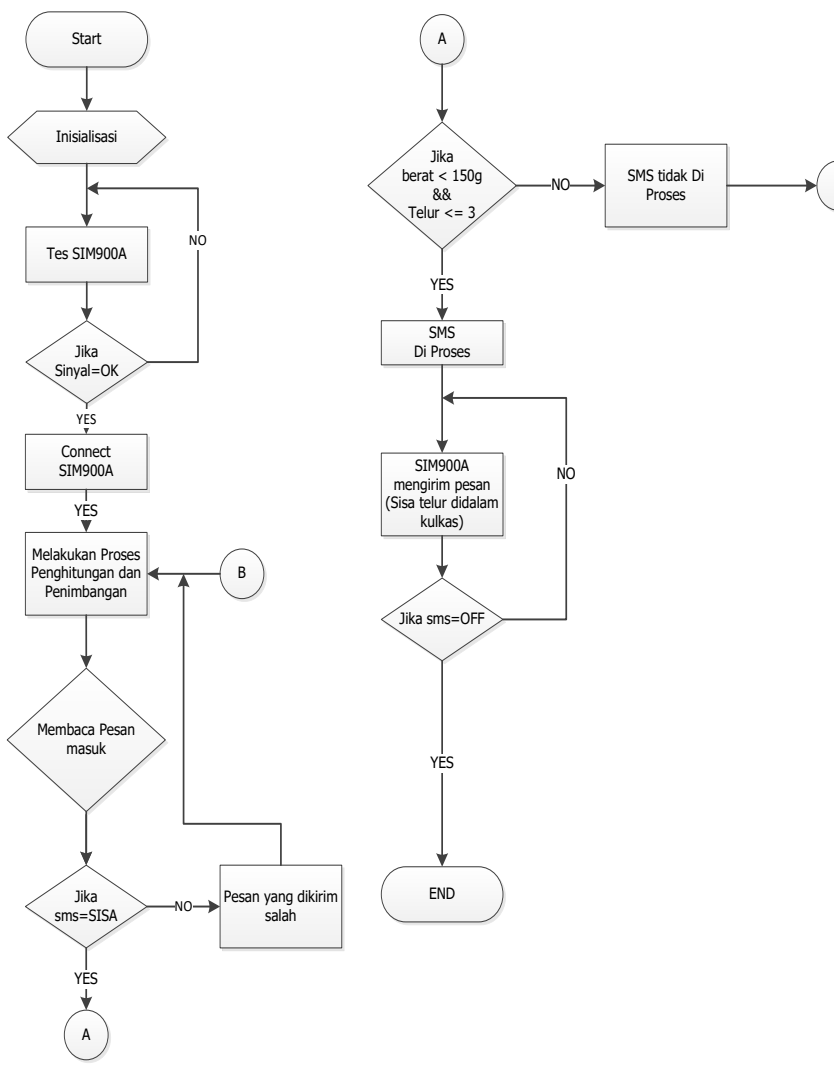

Gambar 8. Flowchart Alat

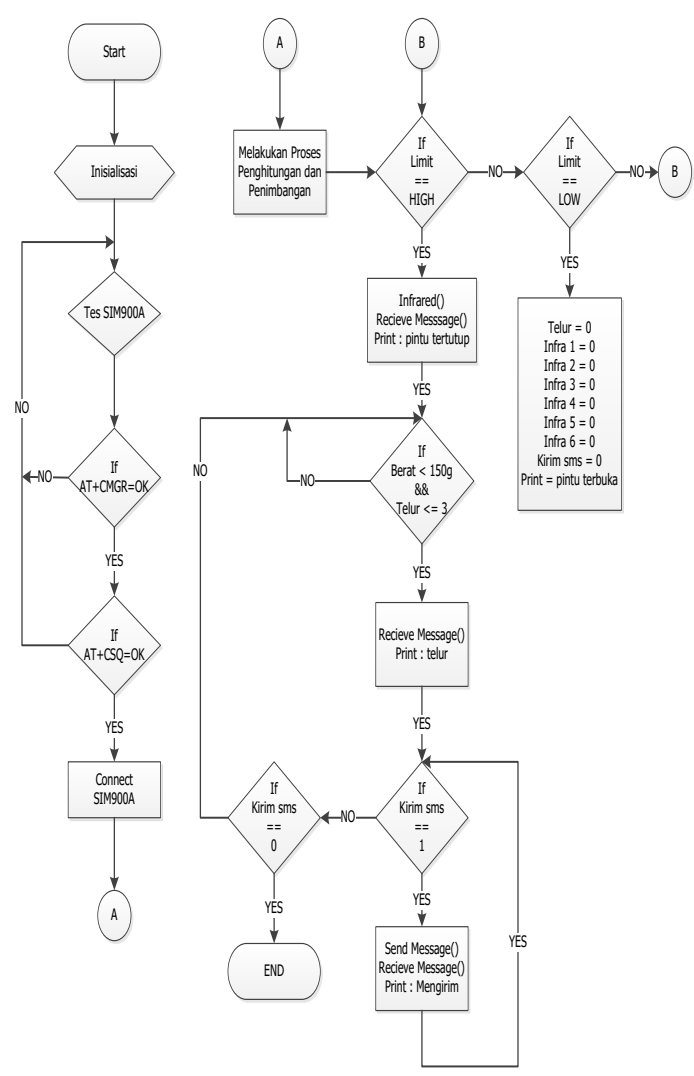

Gambar 9. Flowchart Keseluruhan

\section{B. Pengujian}

\section{Tujuan Pengujian}

Tujuan dari pengukuran sistem ini adalah :

1. Mengetahui apakah perangkat keras yang telah dibuat dapat bekerja dengan baik.

2. Mengetahui perbandingan antara hasil pengujian dengan perancangan, sehingga dapat diketahui apakah kinerja dari sistem berjalan stabil.

3. Dapat diambil kesimpulan-kesimpulan dari hasil pengujian yang didapat sehingga diharapkan pada kemudian hari akan didapat suatu sistem yang dapat bekerja lebih baik dan berguna untuk masyarakat.

\section{Setup Alat}

Setup alat adalah langkah awal yang harus dilakukan supaya peralatan dapat bekerja secara optimal. Menghubungkan antara Arduino Uno R3 dengan beberapa komponen pendukung yang digunakan, tetapi di sini saya hanya akan menjelaskan pin-pin yang digunakan pada perancangan alat saya, dimana masing-masing pin atau port pada Arduino memiliki fungsi atau kendali khusus. Hampir semua pin atau port pada Arduino dapat digunakan sebagai input serta output. Untuk lebih jelasnya, di bawah ini dijelaskan fungsi dari masingmasing pin atau port Arduino yang digunakan.

1. Pin 3 digunkan untuk Infrared 1 untuk mendeteksi jumlah telur.

2. Pin 4 digunkan untuk Infrared 2 untuk mendeteksi jumlah telur.

3. Pin 5 digunkan untuk Infrared 3 untuk mendeteksi jumlah telur.

4. Pin 6 digunkan untuk Infrared 4 untuk mendeteksi jumlah telur.

5. Pin 7 digunkan untuk Infrared 5 untuk mendeteksi jumlah telur.

6. Pin 8 digunkan untuk Infrared 6 untuk mendeteksi jumlah telur.

7. Pin 9 digunkan untuk Limit Switch. 
8. Pin A0 - A1 digunakan untuk Load Cell untuk mendeteksi tekanan atau berat bahan makanan.

9. Pin 10 - 11 digunkan oleh GSM Shield untuk menerima dan mengirim SMS ke nomor yang telah ditentukan.

\section{Upload Software}

Setelah melakukan perancangan dan pembuatan alat, langkah selanjutnya adalah penyususan program untuk pengendalian alat yang disertakan pada sistem ini. Program pengendalian diberikan untuk mengatur proses kerja alat pada masing masing rangkaian. Setiap pengendali yang disusun berbasis kontroler yang dalam hal ini menggunakan IDE Arduino. Bahasa pemrograman yang digunakan sebagai pengatur sistem alat ini adalah bahasa $\mathrm{C}$. Adapun langkah-langkah pemrograman yang dilakukan agar pengendalian tersebut dapat berfungsi sebagaimana mestinya adalah sebagai berikut:

1. Susunan pembuatan program harus sesuai dengan flowchart sebagai alur pengatur.

2. Program dibuat dalam Bahasa $\mathrm{C}$ dan ditulis maupun dikomplikasi menggunakan complier IDE Arduino seperti pada gambar dibawah ini.

3. Kemudaian operator mencari tahu pada port com berapa koneksi USB Arduino yang tersambung kePC atau laptop, hal ini dapat dilihat pada Mycomputer> Manage $>$ Device Manager $>$ Port (COM\&LPT).

4. Setelah itu klik compile lalu Upload

5. Lakukan uji coba terhadap alat yang telah dibuat, apakah sesuai dengan perancangan yang disusun atau tidak. Jika tidak, lakukan pengecekan pada alur program atau rubah program sampai kerja alat sesuai dengan yang diinginkan.

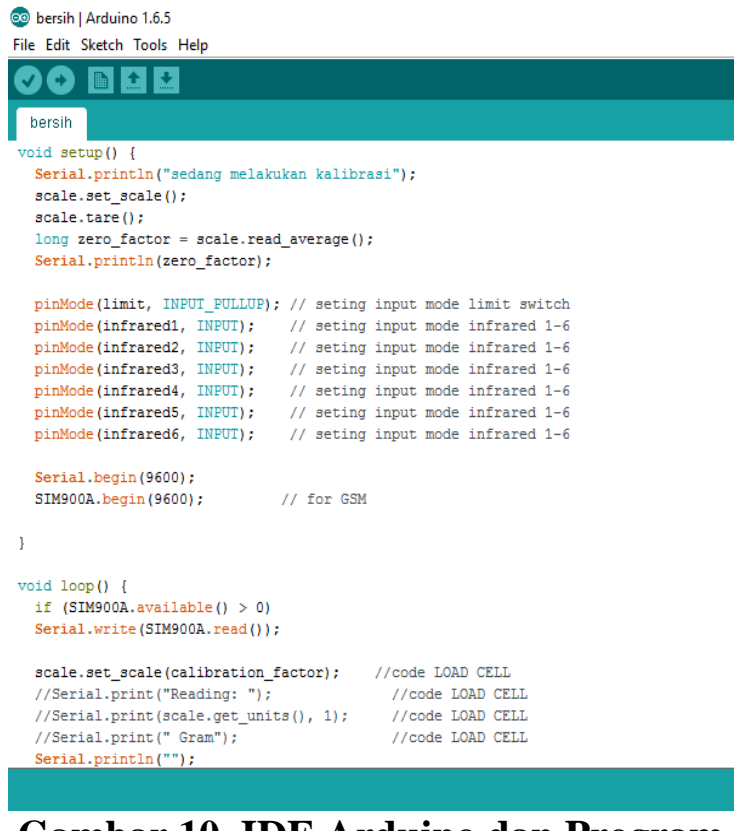

Gambar 10. IDE Arduino dan Program

\section{Pengujian Jarak Sensor Infrared}

Pada dasarnya adalah mengirim lampu infra merah melalui IR-LED, yang kemudian tercermin dari benda apapun yang terdapat di depan sensor. Data hasil pengujian pada sensor Infrared dapat dilihat pada Tabel 2.

Tabel 2. Hasil Pengujian Sensor

\begin{tabular}{lll} 
& & Infrared \\
\hline No & Jarak & Keterangan \\
\hline 1 & $1 \mathrm{Cm}$ & Terdeteksi \\
2 & $2 \mathrm{Cm}$ & Terdeteksi \\
3 & $3 \mathrm{Cm}$ & Terdeteksi \\
4 & $4 \mathrm{Cm}$ & Terdeteksi \\
5 & $5 \mathrm{Cm}$ & Terdeteksi \\
6 & $6 \mathrm{Cm}$ & Tidak terdeteksi \\
7 & $7 \mathrm{Cm}$ & Tidak terdeteksi \\
8 & $8 \mathrm{Cm}$ & Tidak terdeteksi \\
9 & $9 \mathrm{Cm}$ & Tidak terdeteksi \\
10 & $10 \mathrm{Cm}$ & Tidak terdeteksi \\
\hline
\end{tabular}

Pengujian Infrared dan Load Cell

Data hasil pengujian penimbangan pada telur dapat dilihat pada Tabel 3. 
Tabel 3. Hasil Pengujian Infrared dan Load Cell

\begin{tabular}{|c|c|c|c|c|c|c|c|c|c|c|c|c|c|c|c|}
\hline Jumbah & \multicolumn{6}{|c|}{ Peletakan Telur Di Infrared Ke- } & \multirow{2}{*}{\begin{tabular}{|c|} 
Total Berat \\
Telur \\
(Gram) \\
\end{tabular}} & \multirow{2}{*}{\begin{tabular}{|l} 
Jumbhh h \\
Telur
\end{tabular}} & \multicolumn{6}{|c|}{ Peletakan Telur oi Inffrared ke- } & \multirow{2}{*}{\begin{tabular}{|c|} 
Total \\
B Berat \\
Telur \\
\end{tabular}} \\
\hline Tellur & $\mathbb{R} 1$ & $\mathbb{R} 2$ & $\mathbb{R} 3$ & $\mathbb{R} 4$ & $\mathbb{R} 5$ & $\mathbb{R} 6$ & & & $\mathbb{R} 1$ & $\mathbb{R} 2$ & $\mathbb{R} 3$ & $\mathbb{R} 4$ & $\mathbb{R} 5$ & $\mathbb{R} 6$ & \\
\hline 1 & & & & & & & 48,5 & 3 & & & & & & & 160,3 \\
\hline 1 & & & & & & & 48,5 & 3 & & & & & & & 160,3 \\
\hline 1 & & & & & & & 48,5 & 3 & & & & 1) & & & 160,3 \\
\hline 1 & & & & & & & 48,5 & 3 & & & & & & & 160,3 \\
\hline 1 & & & & & & & 48,5 & 3 & & & & & & & 160,3 \\
\hline 1 & & & & & & & 48,5 & 3 & & & & & & & 160,2 \\
\hline
\end{tabular}

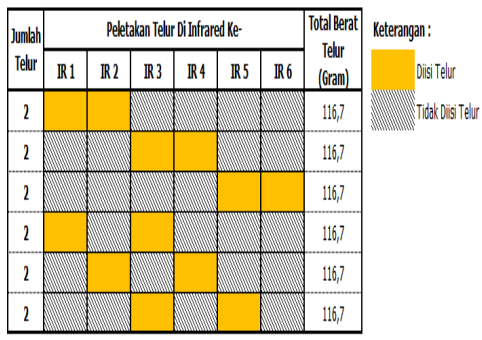

\section{Pengujian Module GSM SIM900A}

Pengujian dilakukan di area yang terbuka, jika di area tertutup kemungkinan sinyal yang didapat pada SIM900A tidak menerima pesan dari smartphone. Saat pengujian diharapkan menggunakan provider yang baik. Jika tidak menggunakan provider yang memiliki sinyal baik akan mempengaruhi pesan yang dikirim oleh smartphone.

\section{Tabel 4. Hasil Pengujian GSM}

\begin{tabular}{lllll|}
\hline No & $\begin{array}{l}\text { Jenis } \\
\text { Provider }\end{array}$ & $\begin{array}{l}\text { Nomor } \\
\text { Provider yang } \\
\text { Digunakan } \\
\text { SIM900A }\end{array}$ & $\begin{array}{l}\text { Waktu } \\
\text { Delay } \\
\text { SMS } \\
\text { (detik) }\end{array}$ & $\begin{array}{l}\text { Nomor yang } \\
\text { digunakan }\end{array}$ \\
\hline 1 & 3 & 089673639432 & $2 ; 2 ; 6 \pm 6$ & 081382365584 \\
2 & M3 & 085811840703 & $2 ; 3 ; 5 \pm 5$ & 081382365584 \\
3 & Telkomsel & 081298428483 & $4 ; 3 ; 2 \pm 4$ & 081382365584 \\
\hline
\end{tabular}

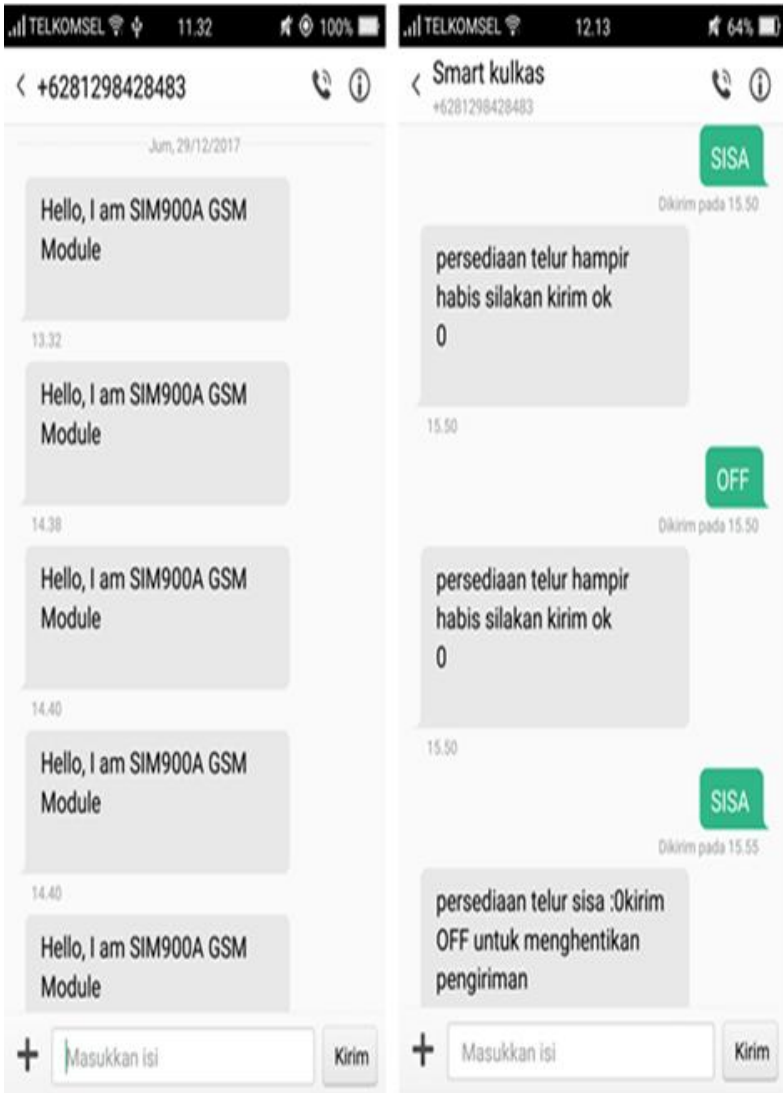

\section{Gambar 11. Pengujian SMS}

\section{Simpulan}

\section{SIMPULAN}

Dari hasil pengujian di atas dapat ditarik kesimpulan sebagai berikut:

1. Sistem Smart Kulkas dapat melakukan deteksi telor dan pengukuran berat bahan makanan di dalam kulkas.

2. Sistem Smart Kulkas dapat memberikan informasi melalui SMS kepada pemilik kulkas mengenai sisa bahan makanan di dalam kulkas.

3. Diperlukan waktu sekitar 5 detik bagi sistem untuk berkomunikasi dengan GSM pemilik kulkas.

\section{Saran}

Prototype Smart kulkas yang telah dirancang, berfungsi untuk meringankan pekerjaan manusia saat berada diluar rumah. Namun alat ini masih memerlukan beberapa penyempurnaan yakni, menambahkan fitur layar touchscreen dan menambahkan fungsi sistem agar dapat 
dikendalikan oleh aplikasi android. Selain itu diharapkan penelitian berikutnya dapat dilakukan jauh lebih baik dengan menggunakan alat yang lebih canggih dibandingkan saat ini.

\section{DAFTAR PUSTAKA}

[1] Baier, L., Rackow, T., Donhauser, T., Pfeffer, D., Schuderer, P. dan Tseng, J. F. Logistical Integration of Smart Homes for Automated Consumer Goods Supply Based on Smart Refrigerators. Advanced Engineering Forum, ISSN: 2234991X, Vol. 19, 107-115. 2016.

[2] Gu, H. and Wang, D. "A Contentaware Fridge Based on Rfid in Smart Home for Home-healthcare, $11^{\text {th }}$ International Conference on Advanced Communication Technology, Vol. 02, 987-990. 2009.

[3] Noutchet, A.D. Novel User Centric Rfid Fridge Design, Computer and Information Science, Vol.6, 151157. 2013.

[4] Xie, L., Yin, Y., Lu, X., Sheng, B., dan Lu, S. Ifridge: An Intelligent Fridge for Food Management Based on Rfid Technology, Proceedings of the 2013 ACM International Joint Conference on Pervasive and Ubiquitous Computing, 291-294. 2013.
[5] Zhang, W., Zhang, Y., Zhai, J., Zhiao, D., Xu, L., Zhou, J. Li, Z. Multi-source data fusion using deep learning for smart refrigerators. Computers in Industry. Vol. 95, 1521. 2018.

[6] Diambil dari situs Arduino. https://store.arduino.cc/arduino-unorev3. (Diakses 1 April 2018).

[7] Diambil dari situs https://researchdesignlab.com/irobstacle-sensor.html. (Diakses 1 April 2018).

[8] Diambil dari situs http://www.htcsensor.com/products/94.html.

(Diakses 1 April 2018).

[9] Diambil dari situs https://www.mouser.com/ds/2/813/h x711_english-1022875.pdf. (Diakses 1 April 2018).

[10]. Rozidi, R.I. Membuat Sendiri SMS Gateway (ESME) Berbasis Protokol $S M P P$. Penerbit Andi Yogyakarta. 2014. 